\title{
Venture Capital: Research Status and Prospects of the Future
}

\author{
(Note 1) \\ Lijun Wang ${ }^{1 *} \&$ Bin $\mathrm{Li}^{2}$ \\ ${ }^{1}$ Department of Finance, Business School, Beijing Technology and Business University, Beijing, China \\ ${ }^{2}$ School of International Trade and Economics, University of International Business of Economics, \\ Beijing, China \\ *Lijun Wang, E-mail: whig_wanglj@126.com
}

\begin{abstract}
This paper reviews recent research results of the venture capital field. The paper indicates that main contents of the theory are that how agency problems brought about by the information asymmetry through the contract design are solved and the value-added management service is provided. A number of empirical evidences provided by documents from some aspects such as the fund raising and the selection of the organization pattern, the project selection as well as the investment contract arrangement, post-investment management activities, withdrawal mechanism as well as the performance and so on are investigated. Problems in the research and possible research directions in the future are also discussed.
\end{abstract}

\section{Keywords}

venture capital, venture firm, asymmetric information, monitor, value-adding services

\section{Introduction}

The birth and growth of new enterprises is the source of the economic development of a country (Bhidé, 1994). Since the foundation of the American Research and Development Corporation (ARD) which was the first formal venture capital institution in 1946, as the investment and financing system innovation, the venture capital had played an important role in some aspects such as supporting entrepreneurial activities of enterprises, promoting the development of strategic emerging industries, improving the efficiency of resource allocation and so on which can improve the whole competitiveness of the economy. The equity investment can be conducted towards unlisted entrepreneurial enterprises with the high-growth potentiality by the venture capital and the value-added management service is provided by the venture capital (Liu, 2004). A lot of innovative enterprises such as Microsoft, Apple, Google, Facebook, Alibaba, Baidu, Tencent, and the like have risen sharply in succession, and have profoundly changed the prospect of the world economy just because of the support of the venture capital.

America is the original place of the venture capital which always occupies most shares. In the past 30 
years, the venture capital industry maintained the significant growth in America. In America, the venture capital amount was approximately 610 million dollars in 1980, while the venture capital amount had grown to 2.3 billion dollars in 1990. After experiencing the 100 billion dollars which reached the peak through the end of the last century with the Internet bubble, although the amount fell, it still remained the scale of more than 30 billion dollars in 2010 (Da Rin, Hellmann, \& Puri, 2013).

The venture capital industry started in the middle of 1980s in China. The Decision on the Reform of the Science and Technology Management System issued in 1985 indicated: "the venture capital can be established to support development of high and new technology development work with the rapid change and the high risk". Subsequently, a number of state-owned capital venture capital institutions such as new technology venture capital companies and so on have been established. In recent years, with the enforcement of a series of laws and regulations such as the Interim Measures for the Management of Venture Capital Enterprises and so on as well as the deepening reform of the capital market, the venture capital industry presents a rapid development momentum in China. According to data statistics of the Zero2IPO Research Center, the total amount of raised funds of the venture capital institutions was 699 million dollars in China in 2004. Since that time, the amount has risen year after year. In 2011, the amount reached to 28 billion and 202 million dollars of the peak period. However, in 2013, the amount fell to 6 billion and 919 million dollars (Note 2).

Increasing concerns of the theoretical research in this field have been promoted by the practical development. Sahlman (1990) argued that the venture capital is the appropriate template of the information economics and the contract theory of agency problems and the like because of operation characteristics of the venture capital. In addition, because of the privacy of venture capital transactions, the data are deficient which has always been a major problem of restricting the development of the empirical study. However, in recent years, with the construction of the commercial database and continuous explorations of some researchers based on the private data, the problem has also been relieved to some extent (Da Rin, Hellmann, \& Puri, 2013).

The paper reviews recent gradually increasing theories and empirical research results of domestic and foreign scholars in the field. The paper indicates that main contributions and to-be solved problems can lay the phased research foundation for the newly-developing but the highly promising research field. Besides, the prosperity of Chinese native venture capital research can be promoted.

The structure of the remaining part of the paper is as follows: firstly, we analyze the theoretical basis and the operation mode of the venture capital; secondly, we discuss the selection of raising and organization forms of the venture capital funds; thirdly, we discuss the project selection of the venture capital investment and the arrangement of the venture capital contract; fourthly, we discuss the post-investment management activity of the venture capital; fifthly, we discuss the withdrawal mechanism and the performance of the venture capital; at last, we conclude and forecast the future research prospect. 


\section{The Theoretical Basis of the Venture Capital and the Operation Mode of the Venture Capital}

\subsection{The Theoretical Basis of the Venture Capital}

The pioneering companies have the typical characteristics, which are different from mature companies. Storey (1994) pointed out that in general, the equity capital gap exists in the growth process of the pioneering companies. The greater external financing restrictions exist in the early-stage innovative companies (European Commission, 2000). However, the higher uncertainty and the risk exist in the pioneering companies in the process of the exploration and the establishment in various aspects of the product, the technology, the market, the management and so on. Besides, the pioneering companies are in the shortage of "hard assets" which are available for the mortgage. The reputation has not been established by the historical record of the management so that the information transparency is lower, and the phenomenon of the information asymmetry is particularly serious (Sahlman, 1990; Murray \& Lott, 1995; Zhang \& Liu, 2000a; Yifu \& Li, 2001; Ueda, 2004).

The "rational discrimination" in the aspect that the required funds provided by the bank is brought about by the above characteristics. The reason is that the financing risk and the transaction costs with high loans cannot be compensated by the bank through the raise of the interest rates because of the existence of the problems of the "adverse selection" and the "credit rationing” (Stiglitz \& Weiss, 1981). Besides, the asymmetry of the income and risk exist in the bank with the credit form to support the pioneering companies. The objective requirements of the long-term effective capital with the "revenue sharing and the risk sharing” of the pioneering companies are not conformed to the credit funds with the debt and the time of the short period (Zhang \& Liu, 2000a). In addition, institutional restrictions are the main factors of impeding the bank to enter the capital market, such as the implicit control of the supervision organization towards the interest rate, the restrictions of the company shareholding right of the bank, the lack of the professional talents, the lack of the incentive plan of the human capital closely linked to the return of the projects and so on (Lerner, Leamon, \& Hardymon, 2012). The entry threshold exists in the public capital market, which requires the companies to provide the operation records of the limited number of years and the performance standard to deliver the sufficient information so that the basic requirements of the effective capital market are met and the interests of the investors are protected. The problems of the equity capital gap of the pioneering companies in the early stage of the growth cannot be solved (Bhidé, 1994; Wang, 2002).

Chan (1983), Chan, Siegel, and Thakor (1990), Sahlman (1990), Qin Ling (2001), Winton and Yerramilli (2008) all pointed out that the venture capitalists have the comparative advantages in the aspect of solving the problem of the information asymmetry. Firstly, the venture capitalists have the special knowledge of the technology, the industry and the market. As the informed investors, good investment projects can be selected by the venture capitalists under the circumstance of the information asymmetry. Besides, the strong supervision can be conducted after the investment. Secondly, some special governance mechanisms for solving the agency problems are developed in the practice, which contain the staged financing, convertible securities, joint investment, the participation of the board of 
directors, the performance compensation based on the value creation and so on. Gompers (1995) believed that entrepreneurs have the private information and seize plenty of the private benefits so that the agency costs are produced. The staged financing is the contract restriction mechanism for solving the potential agency costs, which is conductive to collecting the information regularly, supervising the progress of the companies and reserving the right to terminate the investment for the venture capital. The supervision frequency is higher when the agent problems become more serious and the interval time of the financing is shorter. Brander, Amit and Antweiler (2002) pointed out that the risk sharing, the complementary information before the investment and the shared governance after the investment can be provided by the joint investment.

Bascha and Walz (2001) believed that the stable returns of the investment in the initial stage can be guaranteed and the losses brought about by the investment mistakes can be avoided by the convertible securities for the venture capital. The transformed income of the future growth of the companies can be shared. For the entrepreneurs, the powerful stimulation of the private benefits of control is provided so that the problems of the incentive and restrictive compatibility of the entrepreneurs and the venture capitalists are solved. Cornelli and Yosha (2003) pointed out that the choice right of the withdrawal can be reserved by the staged financing when the venture capitalists receive the bad news of the projects in the middle stage. However, the short-term behavior of the "window dressing" conducted by the entrepreneurs also exists. The possibility of the transformation conducted by the venture capitalists is increased by the convertible securities with the suitable design when the performance is concealed by the entrepreneurs. Plenty of the equities are caused to be transferred to the venture capitalists so that the speculative behavior is limited.

The venture capital can not only reduce the effect of the problems of the information asymmetry through the design of the effective contract mechanism and the conduction of the supervision, but also provide a variety of value-added services of the management to improve the values of the pioneering companies. Zhang and Liu (2000a) believed that entrepreneurs usually lack the management experiences of the companies. The technology, the industry and the development trend of the market can be understood by the management advantages of the capital of the venture capitalists so that a variety of aspects of the operation services of the capital such as the formulation of the long-term development strategy and marketing strategy, the selection of the strategic partners and the key talents, the deployment of the financing arrangements, the reconstruction of the financial structure and so on are provided for the pioneering companies. Besides, the important support of the social credibility is provided. Yu and Qin (2001) believed that the wide social network relationships of the venture capitalists can help the companies to introduce the potential suppliers and customers, establish the distribution channels, recommend the suitable person of the key job and introduce the new investors. Zhang L., Zhang W. and Jiang (2003) believed that the principal-agent relationship exists between the venture capitalists and the entrepreneurs. Besides, the specific resource advantages are possessed by the venture capitalists and the entrepreneurs so that the cooperation and win-win can be developed through 
the repeated game and the establishment of the mutual trust. The theoretical model of the Inderst and Mueller (2009) shows that the speed growth of the pioneering companies can be significantly affected by the venture capitalists. Compared with the companies invested by the passive investors, the competitors can be "preyed on" by the companies invested by the venture capital through the "strategic over-investment" earlier so that the competitive advantages can be maintained towards the competitors of the same industry for long time.

\subsection{The Operation Pattern of the Venture Capital}

The operation pattern of the venture capital is the practical reflection of the above theoretical perspectives. The venture capital companies are established by the venture capitalists who have the experiences of the company management, the industry knowledge and the investment operation. The funds are raised, the projects are selected, the investment contracts are arranged and the management activities are conducted after the investment by the venture capitalists so that the value-added benefits of the capital are obtained with the transfer of the stock equity withdrawal through the ways of the IPO, the merger and so on at last.

The funds of the venture capital are mainly from the qualified investors of the large-scale institutions, wealthy individuals and the like with the patience, the ability of the high risk identification and the bearing ability because of the fact that the funds of the venture capital belong to the private equity investment and require the longer periods. The large-scale institutions contain the pension funds, the donated funds, the insurance companies, the banks and the industrial companies. The funds usually have the specific fundraising scale, the investment strategy and the operation period. $99 \%$ of the total amount is generally put into by the investors while remaining $1 \%$ is put into by the venture capitalists with their own funds. The investment scope can be the specific industries, the specific regions or the specific investment stage. In general, the operation period is 10 years.

The problems of the adverse selection are solved in the project selection process. The information of the deal flow can be obtained by the venture capitalists through the wide range of the channels and network relationships. The basic information of the companies can be realized through the ways of the business plan, the private interviews and the like provided by the companies so that the decision whether to invest on the basis of the certain investment standard is made at last. The potential investment risks require the higher growth expectations for the compensation so that the vast majority of the investment projects which do not meet the standards are removed. The final investment proportion can be maintained at about $1 \%$.

The investment term sheet will be signed between the projects through the selection process and the venture capital, which contains the vast majority of contents of the formal investment contracts. Whether to invest will be confirmed by the venture capitalists. The formal investment contracts will be signed once the decision of the investment is made. The amount of the investment according to the stipulation of the contract will be put into the company account according to the appointed time. The operation of the companies can be supervised by the venture capital after the investment through the 
active management activities and the specific resources can be provided to help the companies grow rapidly so that the maximum of the prospective value can be realized.

As the financial investor, the venture capital does not take the long-term possessing stock right of the companies as the target, but to find the suitable opportunity of the withdrawal to realize the financial returns. The way of the withdrawal mainly has the IPO, the merger and the stock right transfer. The IPO is the favored withdrawal way of the venture capital because of the higher return of the investment and the greater social influence. Although a series of the procedures from the strict selection to the supervision, the operation of parts of the investment projects still fails so that the final investment can be conducted with the way of the liquidation. Since the human capital of the venture capitalists has played the important role in the operation process of the funds, about $20 \%$ of the carried fees of the performance will be obtained by the venture capitalists when the income is allocated except for collecting the management costs covering the operation of the funds.

\section{The Raising and Organization Form Selection of the Venture Capital Funds}

\subsection{The Raising of the Venture Capital Funds}

The empirical research of the venture capital funds raised mainly involves two aspects: one aspect is influencing factors and consequences of the raising fund, and the other aspect is differences of fund contract terms and reasons for the differences of the fund contract terms.

Gompers and Lerner (1998) investigated various factors which affect the whole venture capital industry and the fundraising of the venture capital institutions from 1972 to 1994. Research shows that the demand factor has played a key role in flowing into the venture capital industry for the funds. More entrepreneurial activities are stimulated by the high growth rate of GDP and increased R\&D expenses. Besides, venture capital requirements are increased so that more capital flows into the venture capital industry. The change of capital income tax rates also affects the requirements for the venture capital. More entrepreneurial activities are stimulated by lower tax rates. Besides, investment expected return rates are increased by the increasing requirements so that more capital flows into the venture capital industry. In 1978, the scale of the venture capital is increased by the modification for the "prudent person" clause in the Employee Retirement Incomes Act (ERIsA) by the United States Department of Labor from the supplying point of view. The past performance of the funds is an important factor for affecting the venture capital institutions to raise new funds. The possibility of raising new funds is higher and the scale of the raised new funds is greater with more quantity of the recent IPO of investing enterprises of the venture capital institutions, longer of the established venture capital institutions and greater of the scale of the management funds. Lerner (2002) also analyzes periodic fluctuations of the venture capital market from the supply and demand point of view. He found that the short-term rigidity of the supplying curve is the main reason for affecting the periodic fluctuations of the market. Different from the open capital markets with the high fluidity which makes investors change easily the allocation of the funds, some factors that the interval time of raising new funds by the venture capital institutions 
is longer, the number of experienced investors is very difficult to increase in a short time, organizational challenges are faced with the enlargement of the scale of the management funds, the way of the reporting performance of the funds is conservative and the like bring about the slow adjusting speed of the supplying curve. The fund's self-clearing characteristics of the funds affect market cycle reversely. When the degree of the IPO or merger of the market is high, the fund supply should be increased. However, the investors have received plenty of the returning funds. Otherwise, it would be the opposite. The above research shows that the phenomena of the incomplete competition and the information delay exist in the venture capital market. The balanced scale of the allocation of the funds and the level of the return on investment are difficult to be obtained in the rapidly changing market period. Black and Gilson (1998) investigated the effect of the economy of the capital. They find that the economy of the capital market dominated type is more conductive to the development of the venture capital. The more active the capital market is, the more prosperous the venture capital becomes. Jeng and Wells (2000) found that the condition of the IPO is the main driving factor which affects the periodic cycle of the venture capital with panel data of 21 countries of 10 years from 1986 to 1995. However, the effect of the condition of the IPO towards the market fluctuations of the venture capital of the early-stage investment project from year to year is little.

The condition of the IPO mainly affects the venture capital market of the late-stage investment project. Authors believe that management system of various countries and policy structural differences are possibly the more direct factors which affect the development of the venture capital in different countries. Although the evidence shows that the venture capital with the government background is lack of the sensitivity towards the condition of the IPO, cases of two aspects of both positive and negative aspects of Israel and Germany illustrate that proper government policies and the financial support can still play a strong catalytic role in the development of the venture capital. Leleux and Surlemon (2003) investigated the effect of the government intervention with the data of 15 European countries from 1990 to 1996. They found that the developing scale of the venture capital market of the country of laws towards the investors with lower level of the protection is small. Neither the driving effect of the government investment towards the development of the personal venture capital is supported by the analysis of the panel data, nor the crowding-out effect of the government investment towards the personal investment is supported by the analysis of the panel data. The scale of the government investment delayed reaction towards the market development. Groh, Liechtenstein and Lieser (2010) constructed a comprehensive index to measure the attractiveness towards the venture capital and private equity investors from the national level. According to the review of the documents, they confirm six key driving factors: the economic vitality, the capital market depth, the tax, the investor protection and corporate governance, the human power and social environment and the entrepreneurial culture, and choose 42 variables to measure concretely the six driving factors. Studies of 27 European countries show that England is the most attractive country for VC/PE investors. The following countries are Ireland, Denmark, Sweden, and Norway. The score of Germany is only higher Published by SCHOLINK INC. 
than the average level while scores of France, Italy and Spain are below the average level. The score of every country has a strong positive correlation with the practical fundraising level of the VC/PE market. Gompers and Lerner (2000) investigated the effect of the scale of the capital inflow of the venture capital market towards the level of the project evaluation with 4069 rounds of investment project data of the venture capital from 1987 to 1995 . They found that the increasing scale of the capital inflow can significantly improve the level of the project evaluation. The capital inflow of the most active areas of the venture capital and the industry with the higher attention of the venture capital is maximum. Besides, the level of the project evaluation is higher. This shows that the enterprise value is not only from the expected future cash flow, the promotion of the funds is also the important factor which affects the level of the evaluation.

Gompers and Lerner (1996) investigated two complementary theoretical hypotheses towards the contract terms of the funds. One theoretical hypothesis is that more restrictive terms will be used when the cost of the surveillance is lower or the potential opportunistic behavior is greater because the profit which is brought about by the Limited Partner (LP) is greater than the cost. The other theoretical hypothesis is that the use of the contract terms is to respond to changes of the supply and demand. The increasing demands will not only increase the proportion of management fees, but also reduce many behavior restrictions of the investors of the venture capital. The allocation of the monetary attribute and the private interest in the Pareto effective contract are determined by the two factors of supply and demand. They found that two theoretical hypotheses are obtained the support by using the 140 limited partner agreements of the funds of the venture capital obtained from the institutional investors from 1978 to 1992. As a whole, the effect of the requirement influence is greater. Lerner and Schoar (2004) investigate that why the financial liquidity of the limited partners are limited by the partnership agreement of the funds. They believe that the noise traders who suffer from the liquidity shocks are eliminated by the mobility restriction because of the problem of the information asymmetry so that the adverse selection problem in the follow-up financing of the funds is relieved and the capital costs of the follow-up financing are reduced.

The research of the 243-fund investment partnership agreements in America show that the mobility restriction towards the funds of the limited partners is less when the problem of the information asymmetry s is not very serious.

\subsection{The Organizational Form of the Venture Capital fund}

The partnership is the main organization form of the venture capital companies and the funds in America (Sahlman, 1990; Gompers, 1994; Hsu \& Kenney, 2005). The governance mechanism of the limited partnership was analyzed by Sahlman in the classic document published in 1990.

As the foreign goods, the venture capital industry in China has the significant differences in the aspect of the organizational form. Zhang and Liu (2000b) believed that the venture capitalist market in China of the present stage is not fully developed. The social credit condition and the legal environment are not complete so that the external restriction of the market force towards the general partners is difficult to 
be produced. Hu and Wang (2005) believed that the indirect pricing mechanism is formed by the limited partnership towards the human capital of venture capitalists so that the stimulation problem of the venture capitalists is solved, which is the foundation of the institution of the success of the venture capital in America.

\section{The Project Selection of the Venture Capital and Investment Contract Arrangement}

\subsection{The Project Selection of the Venture Capital}

How to get good deal flow is the first key problem to be solved in the investment stage of the venture capital. Some empirical evidences for referential use are provided by the empirical research documents. Amit (1998) pointed out that comparative advantages of the selecting and supervising the project of the investors of the venture capital are more prominent in the high and new technology industry with the significant information asymmetry. By using the questionnaire survey data of venture capital institutions in Canada from 1991 to 1996, they found that the rate which the venture capital accounts for is higher in the industry with the higher degree of the information asymmetry. Hellmann and Puri (2000) found that enterprises following the innovation not imitating the strategy are likely to obtain the investment of the venture capital with the sample data of 149 newly established firms in Silicon Valley. Lerner (1994) investigates a number of reasons of the joint investment by using 651 rounds of the financing sample data of 271 biotechnology companies obtaining the support of the venture capital from 1978 to 1989. He finds that although the joint investment is very common in the first round of the financing, experienced investors of the venture capital mainly choose investors of the same industry with experiences of the same level to invest jointly so that whether the projects are invested can be judged with more complementary information.

In rounds of the financing in the later period of the enterprises, inexperienced investors of the same industry are also considered when the joint investment is conducted. The intervention of the experienced investors of the venture capital in the rounds of the financing in the later period of the enterprises is often the "window-effect". Although earnings of the strategy are generally low, good market records of the invested projects are provided for the investors of the venture capital so that the follow-up fundraising is convenient. Sorenson and Stuart (2001) investigated that how the transaction space distribution is affected by the mutual network relationship of the investors of the venture capital by using data of the venture capital funds and investment projects from 1986 to 1998 . They found that the investors of the venture capital focus on generally the investment of particular areas or specific industries. However, the network relationship which is established by the joint investment can break through the information barrier to some extent. The transaction distribution range is extended from two aspects of the geographical area and the industry so that the investors of the venture capital who is in the central position in the joint investment benefit from the network relationship. Gompers, Lerner and Scharfstein (2005) investigated influencing factors of the incubation of pioneering enterprises by using the sample data of entrepreneurs who have left the listing corporations and are supported by the venture 
capital to establish new enterprises from 1986 to 1999. They found that pioneering enterprises are apt to be incubated in Silicon Valley or Massachusetts with more concentrated locations of the parent company of the venture capital. More new enterprises will be incubated by specialized operating companies. Besides, these new enterprises tend to the management in the field which is different from the field of the parent company. The view that new starting enterprises with enterprising spirits are easy to be incubated is supported by the research. The reason is that potential entrepreneurs will learn how to establish new enterprises, and obtain required relationship network for the future new enterprises. The bureaucratization of the parent company is also the factor which affects the potential entrepreneurs to leave office and establish new enterprises. Kaplan, Sensoy and Strömberg (2009) investigate how the newly-established enterprises evolve into mature and complicated public companies by using the sample data of 50 companies with the venture capital. They find that the core business or business idea is generally very stable. However, part of the management team changes. Besides, the change of the management team of the company invested by the venture capital is greater than the change of the management team of the company without the investment of the venture capital. Accordingly, authors suggest that the investors of the venture capital should pay more attention to the investigation of the business not the management team when they choose investment projects. By using the data of 136 European venture capital institutions, Patzelt et al. (2009) find that the top management team with the higher proportion of the science or the engineering education background and more entrepreneurial experiences will have the tendency to focus on the early-stage investment strategy. The proportion of the top management team with the higher proportion of the management education background to implement the diversified investment strategy of the industry is greater. The top management team with more international study or employment experiences has the tendency to invest in broader geographical areas.

Bruton and Ahlstrom (2003) investigated the effect of institutional environment by using interview data of 24 venture capital institutions, which invest in China, and three companies which are invested from 1998 to 2000. They find that great differences of the institutional environment of various regions are realized by the investors of the venture capital.

In order to control risk, it is prone to be close to the investment and at least three years of financial management. It is rarely willing to invest in start-up period. Public information is difficult to obtain.

\subsection{The Arrangement of the Investment Contract}

The effective allocation of the residual control rights and the residual claim rights is very important in the investment field of the venture capital because of the information asymmetry and the incomplete contracts. Kaplan and Strömberg (2003) found that the cash flow right, the right of director, the voting right, the liquidation right and other rights of control are allowed to be allocated respectively by the venture capital institutions in the contract by investigating the 213 rounds of the financing behavior and the corresponding contract terms of 119 pioneering companies obtained from the 14 venture capital institutions from 1987 to 1999. In general, the rights are allocated based on the observable performance

Published by SCHOLINK INC. 
indicators in the financial or non-financial aspect. The complete right of control is possessed by the venture capital in the aspects of the right of director, the voting right and the liquidation right when the company performance is bad. When the company performance is improved, the entrepreneurs obtain more rights of control. The cash flow right is reserved by the venture capital while the vast majority of the rights of control and the liquidation rights are abandoned when the company performance is good. Besides, the behavior of leaving the company is restricted by the terms of the competition prohibition and the share cash terms contained in the contract so that the "lock-in" problem is solved. The share cash terms are more common when the stage of the financing is earlier and the "lock-in" problem is more serious. The relationship between the stock right compensation and the performance of the entrepreneurs is more sensitive when the problems of the agency by agreement and the information asymmetry are more serious. Kaplan and Strömberg (2004) by 11 venture capital institutions from 1987 to 1999 years investment of 67 enterprises data investigated how the contract mechanism to solve the principal-agent conflict between venture capitalists and entrepreneurs. The related factors are divided into three categories, which are the internal risk between the management action and the quality of the management team, the external risk of exceeding the control of the management team and the risk of the product/the technology and the business model/the strategy implementation caused by the complexity of the task. More internal risks have the positive correlations with greater proportions of the right of control of the venture capitalists, stronger performance sensitivity of the entrepreneurs and more financing conditions. Risks that are more external have the positive correlations with greater proportions of the right of control of the venture capitalists, stronger performance sensitivity of the entrepreneurs and more financing conditions.

Kaplan, Martel and Strömberg (2007) investigate the differences of the contract terms of the investment by using the 145 investment data of 107 companies of the 74 non-government venture capital institutions in 23 countries from 1992 to 2001. Greater and more experience, and the United States have more exposure to venture capital institutions to cross the barrier of the legal system, and to add more American model of the terms.

Compared with the legal origin, the accounting standards and other legal terms, the experience of the venture capital institutions has more explanatory powers towards the differences of the contract terms. The legal origin, the accounting standards and other legal terms do not have any significant effect.

Yao, Wang and Cheng (2011) are the only original documents to study the contract terms of the VC investment in China at present. They summarize the scale of the relationship between the setting motivation of the terms, the setting of the terms, the effects of the terms, the setting motivation and the setting relationship of the terms, the setting of the terms and the effect relationship of the terms according to the content encoding and the data superposition of the information of the interviews of the 3 cases. They find that the term settings are driven by the information asymmetry, the uncertainty and the new entry defect. The management participation is the most important term setting. The management participation is related with all setting motivations and has the most comprehensive effect 
towards the invested companies. The management participation is the core link of the effect of the setting motivations towards the terms. Besides, the term settings have the effect on the operation of the companies, the company strategy and the company governance. The aspect of the operation is mainly reflected in the term settings.

\section{Post-Investment Management Activities of the Venture Capital}

\subsection{The Supervision Function of the Venture Capital}

The questionnaire survey used in the early studies of Gorman and Sahlman (1989) show that the investors of the venture capital supervise the operation of the company for half the time. As members of the board of directors in the enterprises, 80 hours of the time of the board of directors and 30 hours of the time of the telephone communication are contributed by the investors of the venture capital every year on average.

The financing, the strategic analysis and the recruiting and selecting of the layer of managers layer are the main management participation behavior. Lerner (1995) found that seats of the investors of the venture capital in the board of directors increase significantly when the CEO is changed in the period of various rounds of the financing by using the data of 653 rounds of the financing of 271 biotechnology companies invested by the venture capital from 1978 to 1989. The increase of the seats of the investors of the venture capital in the board of directors means that the investors of the venture capital should make more supervision efforts when the management layer is changed because of the poor performance. The probability is greater when offices of the venture capital are closer to the headquarters of the enterprises. The great probability that the investors of the venture capital can become the members of the board of directors shows that the supervision can be conducted by the venture capital when the geographical position is nearer and the supervised costs are lower. By using the data of nearly 46500 high and new technology pioneering enterprises in Germany, Hegerand (2009) finds that the possibility of the changing of initial management teams of the enterprises is increased by the venture capital. The possibility of the changing of the initial management teams of the enterprises is greater when the offices of the venture capital are closer to the enterprises and the proportion of the shareholding is higher. Gompers (1995) found that the time interval of every round of the investment is shorter when the proportion of the total assets which the tangible assets account for with the measurement of the average level of the industry is lower, the average price-to-book ratio of the industry is higher and the costs of the research and development is greater by using random selecting data of 794 enterprises invested by the venture capital from 1961 to 1992. Tian (2010) found that the investment amount of every round is lower when the venture capital institutions are distant from the invested enterprises, rounds of the investment are more and the time interval of every round is shorter by using data of various sources of the enterprises invested by the venture capital from 1980 to 2006 . The theoretical perspective that the intensity of the supervision should be increased when the agency cost is higher is supported by the above research measuring the severity of agency problems with 
various kinds of indicators.

The effect of the investment of the venture capital towards the discount rate of the IPO attracts wide attentions of scholars. Barry et al. (1990) found that the invested enterprises are supervised by the venture capital through the high proportion of the shareholding and the participation of the board of directors by using the data of 433 companies of the IPO invested by the venture capital and 1123 companies of the IPO without the investment of the venture capital from 1978 to 1987 . The company is invested by the venture capital. The discount rate of the company of the IPO is lower when the time of possessing seats of the directors is longer, the established time is longer, the number of participating in the IPO is more and the proportion of the shareholding of the venture capital is higher. The uncertainty of external investors towards the quality of the IPO is reduced by the investors of the venture capital through the effective supervision so that the discount rate of the IPO is reduced. The effect which the venture capital with the high level exerts on is particularly significant. Megginson and Weiss (1991) find that the first-day return and the total cost rate are significantly lower when the IPO of the company invested by the venture capital is conducted by using the similar sample. The authors believe that the function of the certification delivering the real value and the quality of the companies is possessed by the venture capital towards the external investors in the case of the information asymmetry. The "grandstanding" hypothesis is tested by Gompers (1996), which means that the IPO of the invested companies should be listed as early as possible of the venture capital with the short time of the establishment so that performance records can be produced and new funds can be raised. However, the venture capital with the long time of the establishment, the plentiful experiences and the performance records lack the motivation. They find that the scale of the follow-up raised funds of the venture capital has the significant positive correlation with the number of the IPO companies by using the public samples of the respective first company with the way of the IPO in the investment portfolio of the 62 venture capital funds from 1983 to 1993 and the 433 IPO companies invested by the venture capital from 1978 to 1987. Leeand (2004) find that in the whole period of the samples, the discount of the first day of the IPO of the companies invested by the venture capital is significantly greater than that of the companies without the investment of the venture capital after controlling the endogenous problems by using the data of 6413 IPO companies from 1980 to 2000. The difference is greater in the period of the Internet bubble from 1999 to 2000.

Hu et al. (2012) investigate the effect of the stock participation towards the profit management of the previous year of the listing of the IPO company, the year of the listing and one year after the listing by using the IPO listed 320 companies of the small and medium-sized company stock market and the growth company market in Shenzhen from 2005 to 2009.

They find that the controllability of the joint stock companies of the venture capital listed in the previous year and the year should be accrued negative not significant. Hu et al. (2012) obtain the similar results with the samples of the 280 IPO companies listed on the growth enterprise market from 2009 to 2011. Chen (2010) finds that the degree of the profit management of the IPO companies Published by SCHOLINK INC. 
invested by the venture capital the previous year before the listing is lower with the samples of the 199 IPO companies of the small and medium enterprise board listed companies from 2004 to 2007. Zhang et al. (2012) find that the profit management level before the listing can be significantly reduced by the venture capital with the long time limits of the investment by using the prospectus data of 196 companies of the growth company market from 2009 to 2011. However, the profit management level has been significantly improved by the venture capital of the short period of the time before the listing. Wang and Zhang (2012) find that the salary-performance sensitivity of the layer of the executives of the listed companies invested by the venture capital is higher than the listed companies without the investment of the venture capital. The salary-performance sensitivity of the listed companies invested by the venture capital of the foreign capital is higher. The salary-performance sensitivity of the listed companies invested by the venture capital with the state-owned background is higher than that of the listed companies invested by the venture capital of the privately-operated companies. The salary-performance sensitivity of the listed companies is higher when the proportion of the shareholding of the venture capital is higher, the investment term is longer and the number of the venture capital institutions invested by the companies is more. Jia and Li (2011) find that the underpricing level of the first day of the companies supported by the venture capital is significantly higher than that of the companies without the support of the venture capital by using the research samples of 70 companies supported by the venture capital and 203 companies without the support of the venture capital of the medium and small-sized listed companies from 2004 to 2008. The underpricing degree is higher when the entire period of obtaining the employment is shorter of the venture capital institutions. The underpricing degree of the companies invested by the state-owned venture capital institutions is significantly lower. Ni and Sun (2009) find that the rate of return of the first day of the IPO of the companies invested by the venture capital is significantly higher than that of the companies without the investment of the venture capital by using the data of the daily return rate of the 33 Chinese companies listed on the Nasdaq and the NYSE of the Zero2IPO Research Center database from 1997 to 2006. The long-term performance is also significantly lower after the listing of the companies invested by the venture capital. Chen et al. (2011) find that the discount level of the IPO of the companies invested by the venture capital is significantly higher than that of the companies without the investment of the venture capital in the small and medium-sized board market in China and the main board of the stock market in Hong Kong by using the research samples of 139 Chinese companies supported by the venture capital and 265 Chinese companies without the support of the venture capital from 2004 to 2007. The American market does not have any significant differences. Zhang and Liao (2011) find that the discount rate of the IPO of the listed corporation with shares invested by the foreign capital is significantly lower than that of the state-owned and privately operated listed companies with shares by using the data of 133 the listed corporations with shares obtained by the CV source database. The latter two do not have any significant differences. The further study shows that the cautious investment strategy which the foreign venture capital tends to is reflected when Published by SCHOLINK INC. 
proportion of the shareholding of the largest shareholder in the company supported by the foreign venture capital is lower, the scale of the board of directors is larger, the proportion of professional director is higher, the time of the foreign venture capital from the IPO is shorter, the rounds and the institutions are more and the proportion of the shareholding is larger. The arrangement of the invested company governance structure is more reasonable so that the underpricing rate of the IPO of the company is lower at last.

\subsection{Value-Added Services Function of the Venture Capital}

Hellmann and Puri (2000) studied the sample data of 149 Silicon Valley start-ups, found that the VC investment of enterprises and their products will be faster to the market, especially for enterprises to follow the strategy of innovation. Engel (2002) finds that the increase of the number of enterprise employees invested by the venture capital is significantly higher than the number of enterprise employees without the investment of the venture capital by using the data of new enterprises in Germany. Compared with other investors, the venture capital is conducive to recruiting employees and improving the growth rate of the number of the employees for the companies. Puri and Zarutskie (in press) find that only $0.11 \%$ of new enterprises are invested by the venture capital, but the proportion of employees accounts for $4 \%-5.5 \%$ in 25 years from 1981 to 2005. The growth of the enterprises invested by the venture capital is faster than the new enterprises without the investment of the venture capital whether before the acceptance of the investment of the venture capital or after the acceptance of the investment of the venture capital. Hellmann and Puri (2002) find that the companies invested by the venture capital prefer to connect with the special commercial institution so that the senior executives of the marketing, the public administration and the like are employed from outside by using the mixed data of various sources of 170 newly-established companies in Silicon Valley up to 1997. The analysis of the survey data of senior executives of companies shows that the venture capital has an important influence on the construction of the inner-enterprise organization, particularly the construction of the management team. The enterprises invested by the venture capital are more likely to adopt the stock option plan to attract and stimulate the senior executives, employ the marketing vice-president and replace the founding leaders with the external CEO. Hsu (2004) finds that the financing of the venture capital institutions with the high reputation are easier to be accepted by the pioneering enterprises by using 148 rounds of the financing data of 51 early-stage high-tech pioneering enterprises collected by hand. Besides, compared with the venture capital institutions with the low reputation, $10 \%-14 \%$ discount on average of the stock right of the pioneering enterprises is obtained by the venture capital institutions with the high reputation. Indirect evidences that the venture capital institutions with the high reputation can play the role of value-added services are provided by the research. Lindsey (2008) shows that enterprises invested by the same venture capital are easy to form the alliance relationship by using the data of the enterprise alliance from 1987 to 2001. The proportion of the alliance of the enterprises invested by the venture capital is significantly higher than that of the enterprises without the investment of the venture capital, which illustrates that the venture capital has played a positive role in 
supporting the establishment of the relationships between enterprises. Kortum and Lerner (2000) investigate the relationship between the venture capital and the technological innovation from the level of the industry by using the annual data of 20 manufacturing industries in America from 1965 to 1992. They find that the venture capital has a significant positive effect on the patent application rate. Although when expenses of the venture capital on average account for only less than $3 \%$ of expenses of the research and development from 1983 to 1992, about 8\% of the technological innovation can be explained, which shows that the venture capital is better than the expenses of the research and development to support the enterprise innovation.

Part of the document discusses the impact of VC on the board of directors and other governance mechanisms. Baker and Gompers (2003) find that internal directors and external related directors are fewer when the IPO of companies invested by the venture capital is conducted by using prospectus data of 1116 companies of the IPO from 1978 to 1987. The venture capitalists possess more seats of the board of directors, which shows that the venture capital has played the role of replacing the related external persons to intervene in the company governance actively. The probability of the failure of the operation in 10 years when the IPO of the companies without the investment of the venture capital is conducted is higher. Suchard (2009) finds that the proportion of the board of directors which independent directors account for in the companies invested by the venture capital is higher by using the data of 552 IPO companies from 1994 to 2006 in Australia. More independent directors are industry experts. As members of the board of directors, venture capitalists can help companies employ the industry experts to be the independent directors with the network relationship so that the company governance can be improved. Hochberg (2012) finds that compared with the companies without the investment of the venture capital, the earnings management of the companies invested by the venture capital is lower. The better market reaction exists in the companies invested by the venture capital when the stockholders' rights agreement (for example, the poison pill plan) is adopted. The proportion of the separation between the more external directors, the chairman and the general manager is greater. The governance effect is not shown by other external shareholders without the venture capital.

Dushnitsky and Lenox (2006) examine the role of the Company's subsidiary Venture Capital (CVC). They find that the control of the endogenous CVC investment is positively related to the enterprise Tobin Q value by using the data of 1173 listed companies from 1990 to 1999. The research of the sub-industry shows that the effect mainly exists in the equipment and the information technology industry, which illustrates that the CVC investment has the effect of the "window of the technology" on the parent company. The latest technology and the development tendency of the industry can be grasped. The research of the divisional target shows that the value of the enterprise is significantly increased by the CVC with the strategic investment target. However, the value of the enterprise is not increased by the CVC with the investment target only for obtaining the pure financial income. Authors believe that the CVC cannot obtain the benefit only to pursue the financial income because of some defects of the organization. Lerner (1999) examines the long-term impact of the U.S. government's 
Small Business Innovation Research (SBIR) project on the performance of high tech start-ups with financial support. He finds that in general, the growth rate of sales and the growth rate of the number of the employment of the companies supported by the SBIR are significantly faster than that of the paired companies 1985 to 1995. Besides, the follow-up investment of the private venture capital can be easily obtained. However, the further research shows that the effect is only significant in active areas of the private venture capital and the enterprise from, its growth (rate) and the number of employment growth (rate) are, and more easy to get VC, but this in the private sector and high-tech industries. The company performance cannot be increased by the repeated support of the government towards the pioneering enterprise. The view that the early intervention of government funds can play a role in the certification is supported by the research. Pioneering Companies with good growth opportunities can be selected so that the information asymmetry can be relieved and the follow-up investment of the private venture capital can be promoted. However, the interest group can also capture the pioneering companies so that the investment distortion can be produced.

Some documents directly test the impact of VC investment on enterprise performance. Jain and Kini (1995) find that the price-to-book value ratio and the price-earnings ratio are significantly higher than that of paired samples after two years of the IPO of companies invested by the venture capital from 136 IPO companies invested by the venture capital and the paired samples from 1976 to 1988. However, significant differences do not exist after three years, which shows that the venture capital can still be able to play the certain value-added role in the post-marketing period of the companies. At last, the function is weakened through the withdrawal. The further research shows that performances of the IPO of the companies with the intervention of the venture capital are significantly better. Brav and Gompers (1997) find that the holding-period return of five years of the comparison-sample companies is significantly lower than the IPO companies invested by the venture capital by using 934 IPO companies invested by the venture capital from 1972 to 1992 and 3407 IPO companies without the investment of the venture capital from 1975 to 1992 . The multiple regression result shows that problems of the long-term low performance do not exist in the IPO companies invested by the venture capital while compared with the reference combination; problems of the long-term low performance exist in the IPO companies without the investment of the venture capital with the smallest scale. Krishnan et al. (2011) find that the reputation of the venture capital institutions is positively related to the post-marketing three-year-term performance of companies by using the data of the IPO companies of American market from 1993 to 2004. The further research shows that the probability reserving stock and seats of the board of directors after the IPO of the venture capital institutions with the high reputation in three years is higher. Besides, the venture capital institutions with the high reputation are positively related to the three-year-term performance of the IPO of the companies, which shows that the long-term performance of the IPO of the companies can be improved by the venture capital institutions with the high reputation through the continuous supply of good governance.

Liu (2008) finds that the support of the strategy, the human resource management, the follow-up Published by SCHOLINK INC. 
financing and the relationship network resources are mainly reflected in the positive effect by the venture capital towards the company performance by using effective 143 questionnaires of managers, investment managers and project managers of the venture capital institutions. Ye and Jiang (2009) through $11 \mathrm{VC}$ and investment enterprise research information, found that trust can not only reduce the transaction costs, but also to promote the integration of complementary resources, improve team morale to create value for the enterprise. Zhang and Liao (2011) found that the shares of foreign venture capital shares of the listing Corporation after the listing of the stock market returns were significantly higher than the state-owned and private venture capital shares of listing Corporation, after the two are no significant difference. Wu et al. (2012) find that the phenomenon of the over-investment free cash flow of with the venture capital shares is not serious by using the sample of 291 venture capital institutions and 1384 listed companies from 2002 to 2009. More short-term interest-bearing debts and the external equity financing can be obtained by the venture capital. The external financing environment can be improved by the venture capital institutions with the high proportion of the shareholding, the high reputation, the joint investment or without the state-owned background so that problems of the insufficient investment of the companies with the shortage of the cash can be relieved. More short-term debts can be obtained by the state-owned venture capital institutions.

\section{The Withdrawal Mechanism of the Venture Capital and the Performance}

\subsection{The Withdrawal Mechanism of the Venture Capital}

Limited empirical evidences in the aspect are provided by only a few of the documents. Lerner (1994) finds that the IPO towards the high value of biotechnology companies in the open capital market tends to be conducted by the venture capital by using the data of 350 biotechnology companies invested by the venture capital from 1978 to 1992 . When the value is low in the open capital market, the private financing is dependent on the venture capital. The ability of choosing the time of the venture capital with long-time of obtaining the employment is stronger. Dimov and Shepherd (2005) investigate the effect of human capital attributes of venture capitalists towards the withdrawal of the venture capital institutions by using the sample data of 749 venture capitalists in 303 venture capital institutions with at least the investment of the wireless communication project. They find that the general-type human capital has the positive effect on the withdrawal proportion towards the IPO of companies of the investment portfolio while the special-type human capital has the negative correlation with the proportion of the bankruptcy liquidation of the company of the investment portfolio. The educational background of the science and the humanity as well as working experiences of the law have the positive correlation with the proportion of the bankruptcy liquidation of the company of the investment portfolio. Gompers and Lerner (1998) find that the cumulative abnormal return of stocks before the distribution is significantly positive by using the behavior of the stocks of listed companies directly distributed to the investors of 259 companies possessed by 135 venture capital funds for 731 times in total from 1983 to 1993. However, the continuous negative reaction exists in the market since the 
trading day and in the period after the trading day. The cumulative abnormal return is still significantly negative after one month of the transaction, which shows that the inside information is possessed by the venture capital. The stocks can be distributed with the selection of the market opportunity so that the maximum benefits can be obtained for the fund investors. Field and Hanka (2001) find that transaction amounts permanently increase about $40 \%$ after lifting the ban of the stock right locking protocol agreement by using the data of 1948 IPO companies from 1988 to 1997. The cumulative abnormal return of the stocks from before the day of lifting the ban to after the day of lifting the ban is significantly $-1.5 \%$. Compared with the companies without the investment of the venture capital, the transaction amounts of the stocks and the abnormal returns of the companies invested by the venture capital are greater, which show that compared with the management layer and other stockholders, the stocks will be more actively sold after the day of lifting the ban by the venture capital.

$\mathrm{Li}$ et al. (2003) show that the preference of venture capital companies towards the IPO is higher by using the questionnaire survey results of nearly 30 venture capital companies in Shanghai, Shenzhen, Hefei and other places from July to October in 2002. The proportion of the stock right transfer in the practical withdrawal channel is the highest. The main problems that the trading market of the stock right is not developed, the policies and regulations are not sound, the growth enterprise market is not open and the intermediary agencies are lacking exist in the withdrawal of the venture capital in China.

\subsection{The Research of the Performance of the Performance of the Venture Capital}

The whole information of the cash flow throughout the life cycle of the funds is difficult to be obtained because of the confidentiality of the transactions of the venture capital. The whole performance of the funds is measured roughly according to the proportion through the IPO, the sale or the merger and the withdrawal in the fund portfolio investment companies by the empirical research. Hochberg et al. (2007) find that the proportion through the IPO or the sale and the withdrawal of the investment portfolio companies can be significantly improved by more joint investments by using 47705 rounds of the financing data of 16315 pioneering companies involved in 3469 funds managed by 1974 venture capital institutions from 1980 to 1999. The companies invested by the venture capital with the establishment of good network relationships through the joint investment are more likely to survive to the next round of the financing or conduct the IPO and be sold at last. Establishing the relationship with the investors of the same industry who possess good network relationships is very important for any venture capital institution because more future reciprocal joint investment opportunities can be produced. Nahata (2008) found that the IPO of the companies invested by the venture capital institutions with the high reputation is more likely to be conducted successfully. The companies invested by the venture capital institutions with the high reputation enter the capital market through the IPO or the merger. The asset turnover rate is higher when the IPO is conducted. The analysis of controlling the endogenous shows that the relationship is not only from the excellent investment projects selected by the venture capital institutions with the high reputation before the investment, but also can provide the better value-added services to increase the company value after the investment so 
that the withdrawal performance can be improved. Lindsey (2008) found that VC investment in the establishment of a strategic alliance of enterprises more easily through IPO or by the acquisition of the implementation of the withdrawal. Ozmel et al. (2013) found that more former strategic alliances of the companies will be conductive to the formation of the follow-up strategic alliances by using the data of the biological pioneering companies obtained through multiple channels. However, the crowding-out effect is produced towards the follow-up financing of the venture capital. The follow-up strategic alliances and the financing of the venture capital can be promoted by former more rounds of the financing of the venture capital. The proportion of the withdrawal of the IPO is improved with more rounds of the strategic alliances and the financing of the venture capital and the investment of the venture capital in the center position of the network in the joint investment. The financing of the venture capital is conductive to the merger and the withdrawal. The effect of the strategic alliances towards the merger and the withdrawal is uncertain. Tian (2010) found that the probability of the IPO of companies is greater, the performance of the listed IPO companies is higher and the survival probability of the listing after three years when the venture capital institutions are far from the geographical position of the companies and the rounds of the financing are more by using the data of the shareholding companies of the venture capital with various sources from 1980 to 2006. Chen et al. (2010) found that the proportion of the venture capital institutions and the invested companies concentrating in areas of San Francisco, Boston, and New York is high by using the data in America. Compared with other areas, the proportion of the withdrawal of the invested companies of the venture capital institutions concentrating in areas through the IPO is higher. The better performance of the withdrawal will also be brought about by the venture capital institutions in other areas which invest in the gathering areas. Gompers et al. (2009) investigated the effect of the attention of the venture capital industry towards the investment performance by using the observation data of 20762 venture capitalists possessing the seats of the board of directors of the companies from 1975 to2003. They find that the performance of the venture capital institutions with the high concentration of the industry is better than that of the venture capital institutions with the low concentration of the industry. The reason is possibly that the cross-industry capital of the allocation cannot be conducted efficiently by the venture capital institutions with the low concentration of the industry. The performance of the venture capital institutions with more successful experiences is better.

The relationship between the human capital of the venture capitalists and the performance are involved in the two documents. Bottazzi et al. (2008) found that the venture capitalists with the experiences of the industry or the consulting industry will be more actively involved in employing managers, recommending directors, helping the financing and visiting frequently the invested companies by the questionnaire data of 503 venture capitalists of 119 venture capital institutions of 17 European countries from 1998 to 2001. Compared with the banks, companies and the affiliated venture capital institutions of the government, the company management activities will be more actively intervened by the private independent venture capital institutions. The active participation in the company Published by SCHOLINK INC. 
management activities of the venture capitalists has the positive correlation with the fact that whether the IPO of the company can be realized or the company can be purchased. Zarutskie (2010) investigated the relationship between the attribute of the human capital of the venture capitalists and the performance of the funds by using the data of the complete period of the funds and the information of the 222 venture capitalists who raise the funds for the first time and manage the funds from 1980 to 1998. He finds that the task-specific-type human capital (the venture capitalists have the working experiences of the venture capital previously and the proportion of the venture capitalists who act as the managers previously) and the profession-specific-type human capital (the venture capitalists have the working experiences of the management consultancy) all have the significant positive correlation with the proportion of the IPO or the merger and the withdrawal of the companies and the probability of the follow-up fundraising of the funds.

If Venture capitalists have the background of scientists and engineers, when the proportion of the high-tech pioneering companies invested by the funds is higher, the proportions of the IPO or the merger and the withdrawal of the companies and the follow-up fundraising of the funds are conductive to be improved. If Venture capitalists have other experiences of the financial industry, when the proportion of the pioneering companies invested by the funds in the later stages is higher, the proportions of the IPO or the merger and the withdrawal of the companies and the follow-up fundraising of the funds are conductive to be improved. In contrast to the intuition, the general-type human capital (the proportion of the venture capitalists who have the educational background of the MBA) has the significant negative correlation with the proportion of the IPO or the merger and the withdrawal of the companies. In general, the research shows that the effect of the practical work experiences oriented human capital towards the performance of the funds is greater than that of the general education background, which reflects the importance of the experience accumulation of the venture capital industry.

Kaplan and Schoar (2005) found that the average return on net of the funds after the overall deducting fees is basically equivalent to the S\&P 500 return of the same period by using the data of 746 private equity investment funds from 1980 to 2001. The performance of the venture capital funds surpasses the S\&P from the classification while the buy-out fund return is lower than the S\&P. However, the gross rates of return of two kinds of the funds after the carried interest fees contained by the fund manager all surpass the S\&P. The performance is better when the scale of the funds is greater. However, the declined trend is presented. The follow-up fund performance has the significant positive correlation with the fund performance of the earlier stage, which shows that the fund performance is continuous. The possibility that the follow-up funds raised by the funds collected in the period of the brisk market declines, which shows that the fund performance raised in the period of the brisk market is worse.

Hochberg et al. (2014) found that the performance of the venture capital institutions is continuous with the knowable hard information for the investors of the performance of the fund annual disclosure and the soft information only for the existing investors and the fund managers of the final performance of Published by SCHOLINK INC. 
the end period of the management of the funds by using the data 2257 funds collected by 962 venture capital institutions from 1980 to 2002. The continuity of the performance of the venture capital institutions means that the performance of the former funds has the significant positive correlation with the performance of the follow-up funds. The further evidence shows that the correlation between the final performance (soft information) of the funds and the performance of the follow-up funds is stronger than the correlation between the mid-term public performance (hard information) of the funds and the performance of the follow-up funds. The authors try to explain the phenomenon that the private information is possessed by the existing investors of the funds towards the ability of the fund managers so that the final performance of the funds can be predicted. However, the public information of the realized income of the funds can only be observed by the external potential investors. When the new funds are raised by the fund managers in the mid-term of the management of the funds, the competition of the investors is not sufficient because of the existence of the heterogeneous information. Compared with the external investors, the better decisions can be made by the existing investors and the lock-in phenomenon towards the fund managers can be formed. The realization of the balance between supply and demand of the fund managers through raising fund fees can be prevented so that the performance of the funds of the good venture capital institutions can be sustained. In addition, the study also finds that the operation of 661 venture capital institutions in the sample of 962 venture capital institutions is stopped from 1980 to 2012, which accounts for $68.7 \%$ of the total number of the samples. The study shows that the skill is the scarce factor in the venture capital industry. On average, the operation fails after the establishment of the venture capital institutions for 14.5 years. 2.7 funds are operated in the life cycle on average. The average net IRR is $15.7 \%$ after the remove of the management costs and the performance rewards of the funds. Besides, the fluctuation in different periods of time is very large.

Cochrane (2005) investigated the risk and return of the risk and return of the venture capital projects with the method of the maximum likelihood estimation by using the data of 16613 rounds of the financing of 7765 companies from 1987 to 2000. The estimated average arithmetic return rate after the correction of the selected deviation $698 \%$ to $59 \%$. The arithmetic alpha value reduces from $462 \%$ to $32 \%$. The author finds that the minimum combination of the company stocks of Nada of the same research stage has the similar average return, the volatility and the arithmetic alpha value, which shows that although the return of the invested projects of the venture capital of the research stage is higher, the unique phenomenon does not exist. The research shows that the general trend of the development of the small-scale innovating companies is more likely to be reflected. Krohmer et al. (2009) analyzed the relationship between the staged financing and the investment performance by using the data of 1549 rounds of the investment of 122 funds of the venture capital from 1979 to 2003. The investment density and the investment amount of the initial stage after the three divided stages of the investment have the significant positive correlation with the internal rate of return of the investment, which shows that the final investment performance is better with the higher intensity of the supervision of the early stage of the investment and the lower cost caused by the problems of the information asymmetry and the agency. 
The middle stage of the investment does not have any significant correlations. The investment density and the investment amount of the later stage have the significant negative correlation with the internal rate of return of the investment, which reflects the "window-dressing" behavior of the investment manager. The "window-dressing" behavior of the investment manager means that the liquidation time of the bad investment projects was attempted to be delayed and the losses were attempted to be concealed by putting into more capital frequently and the short-term operation performance is maintained so that the good record signals of the investment of the investment manager can be displayed for the investors. Hochberg and Rauh (2012) found that compared with other institutional investors, the redundant funds are allocated in the local area by the public pension funds by using the data of 3199 funds of the venture capital invested by the 632 institutional investors. Besides, the performance level is reduced by the allocation. The authors believe that this is possibly related with the low management ability of the public pension funds and the political pressure requiring for the investment in the local place.

Qian and Zhang (2007) investigated the rate of return on investment and the affected factors of the projects based on the data of the withdrawal of the 56 Chinese native venture capital projects collected by the questionnaires from 1999 to 2003. They find that the average rate of return on investment of the withdrawal projects of the state-owned venture capital institutions significantly lower than that of the non-state owned venture capital institutions. The capital scale of the venture capital institutions has the significant negative correlation with the rate of return. The rates of return of the withdrawal projects of the venture capital institutions in Shenzhen and Shanghai are significantly higher than that of other regions. Liu and Jiang (2010) found that the withdrawal rate of the venture capital can be improved by the venture capital institutions participating in the joint investment by choosing the 1028 investment events of the 100 venture capital institutions from 1999 to 2005 with the data of the Zero2IPO database and the China Venture database.

\section{The Conclusion and Future Research Prospects}

In the paper, the recent research results of the domestic and foreign scholars are summarized. The theoretical research believes that the high uncertainty and information asymmetry exist in the pioneering companies. As the institutional innovation of the collective investment, the projects can be selected and the value-added services are provided by the specialized knowledge of the venture capitalists. Besides, the special governance mechanism can be developed so that the problems that the agency by agreement and the contract are not complete are solved. The empirical evidences provided by the empirical research shows that the change of the supply and demand and the insufficient competition are the main reasons for affecting the differences of the periodic fluctuation, the fund raising and the contract terms of the venture capital. The venture capitalists tend to choose the industry and the companies with the high information asymmetry so that the competitive advantage is established. Besides, the complementary information is obtained with the wide application of the joint 
investment and the selected range of the projects is extended. The contract terms of the investment have greater differences of different institutional environments, which have the tendency to evolve to the American pattern. The intensity of the supervision is affected by the seriousness of the agency problems and the cost of the supervision. The supervision and the certification of the venture capitalists towards the quality of the companies are delivered through the lower rate of discount of the first day of the IPO. The product development of the companies, the increase of the employees, the professionalization of the management, the technological innovation and the company governance can be promoted by the venture capital and the performance of the companies can be promoted at last. The venture capital will be affected by the market opportunity in the aspect of the withdrawal. The proportion of the withdrawal can be increased by the joint investment, the high reputation, the strategic alliances, the region cluster and the specialization of the investment. The performance of the funds of the venture capital is continuous. However, the characteristic which is higher than the public market portfolio of the same kind is not significantly presented on the whole.

As the emerging field, the significant progress has been made by the venture capital in the aspects of the theoretical and the empirical research. However, some deficiencies still exist, which require to be expanded and improved in the future research. The presentations are the following: firstly, the choice of the financing of the pioneering companies is various. Berger and Udell (1998) find that only $2 \%$ of the equity financing is from the venture capital on the whole by using the survey data of the financing of the national small-scale companies in America. Other channels of the financing contain the angel investment, the bank and the endogenous capital (Amit, Glosten, \& Muller, 1990; Goldfarb et al., 2009; Berger \& Schaek, 2011). Why and how do the companies make the choice between different channels of the financing? The existing research still lacks clear theoretical explanations and empirical evidences. The mutual competition and the complementary effect between different channels of the financing are tested by the systematic and authentic database in the future. Secondly, some problems exist more or less in the data of the existing empirical research documents. Even though the commercial database is established by the system, the omissions and the misrepresentations exist in the commercial database because of the privacy of the transactions of the venture capital. The selection bias of the samples exists in the data obtained through the interview and the specific channel. In addition, the venture capital and the invested companies are at least involved in the transaction so that the mutual choice exists in the market. However, in general, the data of the companies accepting the transaction can be obtained while the data of the companies without the acceptance of the transaction is missing. Besides, the mutual matching and the choice of the contract terms of the pioneering companies and the venture capital can also be affected by the heterogeneity which is not be observed caused by some individual characteristics of both parties of the transaction. How to deal with the selection and treatment effects and the potential endogeneity problems are still the to-be improved problems of many existing researches. Thirdly, the effects of the venture capital has played in the process of the IPO of the companies are investigated by a number of the documents. The documents researching the effect of the 
function and the final withdrawal of the venture capital towards the companies after the IPO of the companies are still scarce. The attention of the mechanism of the function of the venture capital in other withdrawal channels (the merger, the third-party transfer, the trade-in and the like) is not enough except for the IPO. More data should be collected to expand the research. Fourthly, differences which exist in the contract terms in different legal and institutional environments are indicated by some documents. However, the empirical evidences of the connection between the choices of different contract terms and the economic consequences are lacking. The present research that how to sign the contract, what factors affect the contract and what kinds of the economic consequences will be brought about by the differences of the contract terms in the specific legal and institutional environments in China is almost blank. More private information of the transaction contract between the investors and the venture capital as well as between the venture capital and the invested companies should be obtained in the future. Fifthly, a few the empirical researches of the Chinese scholars focus on the effect of the venture capital towards the discount rate of the IPO and the profit management. However, the existing research conclusions are not consistent because of the greater differences in the aspects of the sample selection, the research methods and the like. The empirical researches with other dimensions are scarce so that the empirical research based on the institutional background in China is required in the future. For example, what are the differences of the joint investment with the state-owned background, the privately operated background and the foreign capital background in the aspects of the fund raising, the project selection, the investment arrangement, the management after the investment and the withdrawal? How to measure the reputation of the venture capital institutions and the effect in China? Are the mechanisms of the staged investment, the joint investment and the like are used generally? Can the joint investment play the effect? What are the rates of return of the funds of the venture capital, the affected factors and the like in China?

\section{References}

Admati, A., \& Pfleiderer, P. (1994). Robust financial contracting and the role of venture capitalists. Journal of Finance, 49, 371-402.

Amit, R., Brander, J., \& Zott, C. (1998). Why do venture capital firms exist? Theory and Canadian evidence. Journal of Business Venturing, 13, 441-466.

Amit, R., Glosten, L., \& Muller, E. (1990). Entrepreneurial ability, venture investments, and risk sharing. Management Science, 36, 1232-1245.

Baker, M., \& Gompers, P. (2003). The determinants of board structure at the initial public offering. Journal of Law and Economics, 46, 569-598.

Barry, C., Muscarella, C., Peavy, J., \& Vetsuypens, M. (1990). The role of venture capital in the creation of public companies: Evidence from the going public process. Journal of Financial Economics, 27, 447-471.

Bascha, A., \& Walz, U. (2001). Convertible securities and optimal exit decisions in venture capital Published by SCHOLINK INC. 
finance. Journal of Corporate Finance, 7, 285-306.

Bergemann, D., \& Hege, U. (1998). Venture capital financing, moral hazard, and learning. Journal of Banking and Finance, 22, 703-735.

Berger, A., \& Schaek, K. (2011). Small and medium-sized enterprises, bank relationship strength, and the use of venture capital. Journal of Money, Credit and Banking, 43, 461-490.

Berger, A., \& Udell, G. (1998). The economics of small business finance: The roles of private equity and debt markets in the financial growth cycle. Journal of Banking and Finance, 22, 613-673.

Berglöf, E. (1994). A control theory of venture capital finance. Journal of Law, Economics and Organization, 10, 247-267.

Bhidé, A. (1994). The origin and evolution of new businesses. Oxford: Oxford University Press.

Black, B., \& Gilson, R. (1998). Venture capital and the structure of capital markets: Banks versus stock markets. Journal of Financial Economics, 47, 243-277.

Bottazzi, L., Da Rin, M., \& Hellmann, T. (2008). Who are the active investors? Evidence from venture capital. Journal of Financial Economics, 89, 488-512.

Bottazzi, L., Da Rin, M., \& Hellmann, T. (2009). What is the role of legal systems in financial intermediation? Theory and evidence. Journal of Financial Intermediation, 18, 559-598.

Brander, J., Amit, R., \& Antweiler, W. (2002). Venture capital syndication: Improved venture selection versus the value-added hypothesis. Journal of Economics and Management Strategy, 11, 423-452.

Brav, A., \& Gompers, P. (1997). Myth or reality? The long-run underperformance of initial public offerings: Evidence from venture- and non venture-capital-backed companies. Journal of Finance, 52, 1791-1821.

Brav, A., \& Gompers, P. (2003). The role of lockups in initial public offerings. Review of Financial Studies, 16, 1-29.

Broughman, B., \& Fried, J. (2010). Renegotiation of cash flow rights in the sale of VC-backed firms. Journal of Financial Economics, 95, 384-399.

Bruton, G. D., \& David, A. D. (2003). An institutional view of China's venture capital industry: Explaining the differences between China and the West. Journal of Business Venturing, 18, 233-259.

Casamatta, C. (2003). Financing and advising: Optimal financial contracts with venture capitalists. Journal of Finance, 58, 2059-2086.

Chan, Y. (1983). On the positive role of financial intermediation in allocations of venture capital in a market with imperfect information. Journal of Finance, 38(5), 1543-1561.

Chan, Y. S., Siegel, D., \& Thakor, A. (1990). Learning, corporate control and performance requirements in venture capital contracts. International Economic Review, 31, 365-381.

Chemmanur, T., Krishnan, K., \& Nandy, D. (2011). How does venture capital financing Improve efficiency in private firms? A look beneath the surface. Review of Financial Studies, 24, 4037-4090. 
Chen, G. M., Yu, X., \& Kou, X. H. (2011). The underpricing of Venture Capital Backed IPOs: Evidence from Chinese Firms Listed on Different Stock Markets. Economic Research Journal, 5, 74-85.

Chen, H., Gompers, P., Kovner, A., \& Lerner, J. (2010). Buy local? The geography of venture capital. Journal of Urban Economics, 67, 90-102.

Chen, X. Y. (2010). The Empirical Research on Venture Capital and Earnings Management of IPO Firms. Research on Financial and Economic Issues, 1, 64-69.

Chen, Y. G., \& Wang, S. S. (2007). The Empirical Research on Venture Capital IPO low pricing and Exit Performance. Securities Market Herald, 10, 60-64.

Cochrane, J. (2005). The risk and return of venture capital. Journal of Financial Economics, 75, 3-52.

Cornelli, F., \& Yosha, O. (2003). Stage financing and the role of convertible securities. Review of Economic Studies, 70, 1-32.

Da Rin, M., Hellmann, T. F., \& Manju, P. M. (2013). A survey of venture capital research. Handbook of the Economics of Finance.

Dimov, D. P., \& Shepherd, D. A. (2005). Human capital theory and venture capital firms: Exploring "home runs" and "strike outs". Journal of Business Venturing, 20, 1-21.

Dushnitsky, G., \& Lenox, M. J. (2006). When does corporate venture capital investment create firm value? Journal of Business Venturing, 21, 753-772.

Engel, D. (2002). The impact of venture capital on firm growth: An empirical investigation (ZEW working paper). No. 02-02.

European Commission. (2000). The European Observatory for SMEs (Sixth Report).

Goldfarb, B., Hoberg, G., Kirsch, D., \& Triantis, A. (2009). Does angel participation matter? An analysis of early venture financing (Unpublished working paper).

Gompers, P. (1994). The rise and fall of venture capital. Business and Economic History, 23, 1-26.

Gompers, P. (1995). Optimal investment, monitoring, and the staging of venture capital. Journal of Finance, 50, 1461-1489.

Gompers, P. (1996). Grandstanding in the venture capital industry. Journal of Financial Economics, 42, 133-156.

Gompers, P., \& Lerner, J. (1996). The use of covenants: An empirical analysis of venture partnership agreements. Journal of Law and Economics, 39, 463-498.

Gompers, P., \& Lerner, J. (1998a). Venture capital distributions: Short-run and long-run reactions. Journal of Finance, 53, 2161-2183.

Gompers, P., \& Lerner, J. (1998b). What drives venture capital fundraising (Brookings Papers on Economic Activity)? Microeconomics, 149-192.

Gompers, P., \& Lerner, J. (1999a). Conflict of interest in the issuance of public securities: Evidence from venture capital. Journal of Law and Economics, 42, 1-28.

Gompers, P., \& Lerner, J. (1999b). An analysis of compensation in the US venture capital partnership. Journal of Financial Economics, 51, 3-44. 
Gompers, P., \& Lerner, J. (2000). Money chasing deals? The impact of fund inflows on private equity valuation. Journal of Financial Economics, 55, 281-325.

Gompers, P., \& Lerner, J. (2001). The venture capital revolution. Journal of Economic Perspectives, 15, 145-168.

Gompers, P., Kovner, A., Lerner, J., \& Scharfstein, D. (2008). Venture capital investment cycles: The impact of public markets. Journal of Financial Economics, 87, 1-23.

Gompers, P., Lerner, J., \& Scharfstein, D. (2005). Entrepreneurial spawning: Public corporations and the genesis of new ventures, 1986 to 1999. Journal of Finance, 60, 577-614.

Gompers, P., Lerner, J., Scharfstein, D., \& Kovner, A. (2010). Performance persistence in entrepreneurship. Journal of Financial Economics, 96, 18-32.

Gorman, M., \& Sahlman, W. (1989). What do venture capitalists do? Journal of Business Venturing, 4, 231-248.

Groh, A. P., Liechtenstein, H, \& Lieser. K. (2010). The European Venture Capital and Private Equity country attractiveness indices. Journal of Corporate Finance, 16, 205-224.

Guo, J. L. (2004). Research on Dual Principal and Agent Mechanism of Venture Capital Fund. Nankai Economic Studies, 1, 100-104.

Hellmann, T. (1998). The allocation of control rights in venture capital contracts. RAND Journal of Economics, 29, 57-76.

Hellmann, T. (2002). A theory of strategic venture investing. Journal of Financial Economics, 64, 285-314.

Hellmann, T. (2006). IPOs, acquisitions, and the use of convertible securities in venture capital. Journal of Financial Economics, 81, 649-679.

Hellmann, T., \& Puri, M. (2000). The Interaction between product market and financing strategy: The role of venture capital. Review of Financial Studies, 13, 959-984.

Hellmann, T., \& Puri, M. (2002). Venture capital and the professionalization of start-up firms: Empirical evidence. Journal of Finance, 57, 169-197.

Hellmann, T., Lindsey, L., \& Puri, M. (2008). Building relationships early: Banks in venture capital. Review of Financial Studies, 21, 513-541.

Hochberg, Y. (2012). Venture capital and corporate governance in the newly public firm. Review of Finance, 16(2), 429-480.

Hochberg, Y., \& Rauh, J. (2012). Local Overweighting and Underperformance: Evidence from Limited Partner Private Equity Investments. Review of Financial Studies, 26(2), 403-451.

Hochberg, Y., Ljungqvist, A., \& Vissing-Jørgensen, A. (2014). Informational Holdup and Performance Persistence in Venture Capital. Review of Financial Studies, 27(1), 102-152.

Hochberg, Y., Ljungqvist, A., \& Lu, Y. (2007). Whom you know matters: Venture capital networks and investment performance. Journal of Finance, 62, 251-301.

Hochberg, Y., Ljungqvist, A., \& Lu, Y. (2010). Networking as a barrier to entry and the competitive Published by SCHOLINK INC. 
supply of venture capital. Journal of Finance, 65, 829-859.

Hsu, D. (2004). What do entrepreneurs pay for venture capital affiliation? Journal of Finance, 59, 1805-1844.

Hsu, D., \& Kenney, M. (2005). Organizing venture capital: The rise and demise of American Research \& Development Corporation, 1946-1973. Industrial and Corporate Change, 14, 579-616.

Hu, H. F. (2002). Contract of Venture Capital: Theory Review and Future. Nankai Economic Studies, 3, 64-66.

Hu, H. F., \& Wang, J. (2005). The Practice of Venture Capital in U.S.A. Management World, 10, 164-165.

Hu, Z. Y., Zhou, L., \& Liu, Y. (2012). Venture Capital, Syndicate Diversity and the Accounting Information Quality of IPO Companies in ChiNext Market. Accounting Research, 7, 48-56.

Hu, Z., Cai, W., Han, J., \& Sa, R. (2012). An empirical study of the effect of venture capital participation on the accounting information quality of IPO firms. China Journal of Accounting Research, 5, 251-268.

Inderst, R., \& Müller, H. (2004). The effect of capital market characteristics on the value of start-up firms. Journal of Financial Economics, 72, 319-356.

Inderst, R., \& Müller, H. (2009). Early-stage financing and firm growth in new industries. Journal of Financial Economics, 93, 276-291.

Jain, B. A., \& Kini, O. (1995). Venture capitalist participation and the post-issue operating performance of IPO firms. Managerial and Decision Economics, 16(6), 593-606.

Jeng, L., \& Wells, P. (2000). The determinants of venture capital funding: Evidence across countries. Journal of Corporate Finance, 6, 241-289.

Jia, N., \& Li, D. (2011). The Effect of Venture Capital on the Performance of IPO Companies. Nankai Business Review, 1, 96-106.

Kanniainen, V., \& Keuschnigg, C. (2004). Start-up investment with scarce venture capital support. Journal of Banking and Finance, 28, 1935-1959.

Kaplan, S., \& Schoar, A. (2005). Private equity performance: Returns, persistence, and capital flows. Journal of Finance, 60, 1791-1823.

Kaplan, S., \& Strömberg, P. (2003). Financial contracting theory meets the real world: An empirical analysis of venture capital contracts. Review of Economic Studies, 70, 281-315.

Kaplan, S., \& Strömberg, P. (2004). Characteristics, contracts, and actions: Evidence from venture capitalist analyses. Journal of Finance, 59, 2177-2210.

Kaplan, S., Martel, F., \& Strömberg, P. (2007). How do legal differences and experience affect financial contracts? Journal of Financial Intermediation, 16, 273-311.

Kaplan, S., Sensoy, B., \& Strömberg, P. (2009). Should investors bet on the jockey or the horse? Evidence from the evolution of firms from early business plans to public companies. Journal of Finance, 64, 75-115. 
Kirilenko, A. (2001). Valuation and control in venture finance. Journal of Finance, 56, 565-587.

Kortum, S., \& Lerner, J. (2000). Assessing the contribution of venture capital to innovation. RAND Journal of Economics, 31, 674-692.

Krishnan, C., Masulis, R., Ivanov, V., \& Singh, A. (2011). Venture capital reputation, post-IPO performance and corporate governance. Journal of Financial and Quantitative Analysis, 46, 1295-1333.

Krohmer, P., Lauterbach, R., \& Calanog, V. (2009). The bright and dark side of staging: Investment performance and the varying motivations of private equity firms. Journal of Banking \& Finance, 33, 1597-1609.

Lee, P., \& Wahal, S. (2004). Grandstanding, certification and the underpricing of venture capital backed IPOs. Journal of Financial Economics, 73, 375-407.

Leleux, B., \& Surlemont, B. (2003). Public versus private venture capital: Seeding or crowding out? A pan-European analysis. Journal of Business Venturing, 18, 81-104.

Lerner, J. (1994a). Venture capitalists and the decision to go public. Journal of Financial Economics, 35, 293-316.

Lerner, J. (1994b). The syndication of venture capital investments. Financial Management, 23, 16-27.

Lerner, J. (1995). Venture capitalists and the oversight of private firms. Journal of Finance, 50, 301-318.

Lerner, J. (1999). The government as venture capitalist: The long-run impact of the SBIR program. Journal of Business, 72, 285-318.

Lerner, J. (2002). Boom and Bust in the Venture Capital Industry and the Impact on Innovation. Economic Review, 25-39.

Lerner, J., \& Schoar, A. (2004). The illiquidity puzzle: Theory and evidence from private equity. Journal of Financial Economics, 72, 3-40.

Lerner, J., Leamon, A., \& Hardymon, F. (2012). Venture capital, Private equity, and the financing of entrepreneurship. John Wiley \& Sons, Inc.

Lerner, J., Schoar, A., \& Wongsunwai, W. (2007). Smart institutions, foolish choices? The limited partner performance puzzle. Journal of Finance, 62, 731-764.

Li, Y. K. et al. (2003). Investigation on Exit of Venture Capital. Economic Theory and Business Management, 2, 66-70.

Lin, Y. F., \& Li, Y. J. (2001). Promoting the Growth of Medium and Small-sized Enterprises through the Development of Medium and Small-sized Financial Institutions. Economic Research Journal, $1,10-18$.

Lindsey, L. (2008). Blurring firm boundaries: The role of venture capital in strategic alliance. Journal of Finance, 63, 1137-1168.

Mayer, C., Schoors, K., \& Yafeh, Y. (2005). Sources of funds and investment activities of venture capital funds: Evidence from Germany, Israel, Japan and the United Kingdom. Journal of 
Corporate Finance, 11, 586-608.

Megginson, W., \& Weiss, K. (1991). Venture capitalist certification in initial public offerings. Journal of Finance, 46, 879-903.

Metrick, A., \& Yasuda, A. (2010). The economics of private equity funds. Review of Economic Studies, 23, 2303-2341.

Metrick, A., \& Yasuda, A. (2011). Venture capital and other private equity: A survey. European Financial Management, 17, 619-654.

Murray, G., \& J. Lott. (1995). Have UK Venture Capitalists a Bias against Investments in New Technology-Based Firms? Research Policy, 24(2), 283-299.

Nahata, R. (2008). Venture capital reputation and investment performance. Journal of Financial Economics, 90, 127-151.

Ozmel, U., Robinson, D., \& Stuart, T. (2013). Strategic alliances, venture capital, and exit decisions in early stage high-tech firms. Journal of Financial Economics, 107, 655-670.

Patzelt, H., Knyphausen-Aufseß, D., \& Fischer, H. (2009). Upper echelons and portfolio strategies of venture capital firms. Journal of Business Venturing, 24, 558-572.

Puri, M., \& Zarutskie, R. (in press). On the lifecycle dynamics of venture-capital and non-venture-capital-financed firms. Journal of Finance.

Qian, P., \& Zhang, W. (2007). Returns on Chinese Venture Capital Investment and Its Determinants. Economic Research Journal, 5, 78-90.

Sahlman, W. (1990). The structure and governance of venture-capital organizations. Journal of Financial Economics, 27, 473-521.

Schmidt, K. (2003). Convertible securities and venture capital finance. Journal of Finance, 58, 1139-1166.

Sørensen, M. (2007). How smart is smart money? A two-sided matching model of venture capital. Journal of Finance, 62, 2725-2762.

Sorenson, O., \& Stuart, T. (2001). Syndication networks and the spatial distribution of venture capital investments. American Journal of Sociology, 106, 1546-1588.

Stiglitz, J. E., \& Weiss, A. (1981). Credit rationing in markets with imperfect information. American Economic Review, 71(3), 393-410.

Storey, D. J. (1994). Understanding the Small Business Sector. London: Routlege.

Suchard, J. (2009). The impact of venture capital backing on the corporate governance of Australian initial public offerings. Journal of Banking \& Finance, 33, 765-774.

Tian, X. (2011). The causes and consequences of venture capital stage financing. Journal of Financial Economics, 101, 132-159.

Ueda, M. (2004). Banks versus venture capital: Project evaluation, screening, and expropriation. Journal of Finance, 59, 601-621.

Wang, H. J., \& Zhang, R. (2012). Private Equity Investment and Management Team Incentive Published by SCHOLINK INC. 
Alignment. Management World, 9, 156-167.

Wang, S. Q., \& Ding, R. (2001). Venture Capital organization and Agency Cost. Journal of Financial Research, 12, 73-80.

Winton, A., \& Yerramilli, V. (2008). Entrepreneurial finance. Banks versus venture capital. Journal of Financial Economics, 88, 51-79.

Wu, C. P. et al. (2012). The Role of Venture Capital in the Investment and Financing Behavior of Listed Companies: Evidence from China. Economic Research Journal, 1, 105-119.

Yao, Z., Wang, X. Y., \& Cheng, Y. K. (2011). A Study on the Motivation of the Stimulation of Terms in the Contracts for Risk Investment and on its Affecting Mechanism. Management World, 2, 127-141.

Zarutskie, R. (2010). The role of top management team human capital in venture capital markets: Evidence from first-time funds. Journal of Business Venturing, 25, 155-172.

Zhang, D. S., \& Liu, J. J. (2000). The Discussions of Organizational Stucture and legel Frame of Venture Fund in China. Journal of Financial Research, 6, 1-10.

Zhang, X. Y., \& Liao, L. (2011). VCs' Backgrounds, IPO Underpricing and Post-IPO Performance. Economic Research Journal, 6, 118-132.

\section{Notes}

Note 1. This research is supported by Beijing Natural Science Foundation project No. 9122005, Collaborative Innovation Centre for State-owned Assets Administration of Beijing Technology and Business University project No. GZ20131101.

Note 2. Data from the Venture Capital annual research report in China in 2013 of the research center. 